Published in final edited form as:

Nitric Oxide. 2018 September 01; 79: 38-44. doi:10.1016/j.niox.2018.07.003.

\title{
Nitro-fatty acid Formation and Metabolism
}

\author{
Gregory R. Buchan ${ }^{1,{ }^{\star}}$, Gustavo Bonacci ${ }^{2,{ }^{*},}$, Marco Fazzari ${ }^{1,3}$, Sonia Salvatore ${ }^{1}$, and Stacy \\ Gelhaus Wendell ${ }^{1,4}$ \\ ${ }^{1}$ Department of Pharmacology \& Chemical Biology, University of Pittsburgh, Pittsburgh, PA \\ 15261, USA \\ 2. $\mathrm{CIBICI}$ - CONICET, Departamento de Bioquímica Clínica Facultad de Ciencias Químicas \\ (U.N.C.) Haya de la Torre y Medina Allende Ciudad Universitaria, Córdoba C.P. Nº: X5000HUA, \\ República Argentina \\ 3.Fondazione Ri.MED, Via Bandiera 11, 90133 Palermo, Italy \\ 4. Clinical Translational Science Institute, University of Pittsburgh, Pittsburgh, PA 15261, USA
}

\begin{abstract}
Nitro-fatty acids $\left(\mathrm{NO}_{2}\right.$-FA) are pleiotropic modulators of redox signaling pathways. Their effects on inflammatory signaling have been studied in great detail in cell, animal and clinical models primarily using exogenously administered nitro-oleic acid. While we know a great deal about their signaling, endogenous $\mathrm{NO}_{2}$-FA formation and metabolism is relatively unexplored. This review will cover what is currently known regarding proposed mechanisms of formation, dietary modulation of endogenous $\mathrm{NO}_{2}$-FA levels, and pathways of metabolism and detection of $\mathrm{NO}_{2} \mathrm{FA}$ and corresponding metabolites.
\end{abstract}

\section{Keywords}

nitric oxide; nitrogen dioxide; nitration; nitro-fatty acid; metabolism; nitro-conjugated linoleic acid; diet

\section{Nitro-Fatty Acid Formation and Metabolism}

\begin{abstract}
Metabolism of nitric oxide ( $\left.{ }^{\circ} \mathrm{NO}\right)$ and the production of nitrogen oxides under pathophysiological conditions generates nitrosating (R-NO) and nitrating $\left(\mathrm{R}-\mathrm{NO}_{2}\right)$ species that react with proteins, unsaturated fatty acids and thiol-containing small molecules such as glutathione (GSH) (1-4). The nitration of unsaturated fatty acids by the radical nitrogen dioxide $\left({ }^{\circ} \mathrm{NO}_{2}\right)$ generates electrophilic, bioactive lipids that form covalent Michael addition
\end{abstract}

\footnotetext{
Corresponding Author: Stacy Gelhaus Wendell, 200 Lothrop Street, E1340, Pittsburgh, PA 15261, gstacy@ pitt.edu. Co-first authors

Publisher's Disclaimer: This is a PDF file of an unedited manuscript that has been accepted for publication. As a service to our customers we are providing this early version of the manuscript. The manuscript will undergo copyediting, typesetting, and review of the resulting proof before it is published in its final form. Please note that during the production process errors may be discovered which could affect the content, and all legal disclaimers that apply to the journal pertain.

Declaration of Interests. SGW acknowledges financial interest in Complexa, Inc.
} 
adducts with nucleophilic amino acids, predominantly cysteine, found in transcriptional regulatory proteins and enzymes involved in metabolism, cell signaling and redox homeostasis $(5,6)$. Post translational modification (PTM) by $\mathrm{NO}_{2}$-FA has been demonstrated to lead to profound functional changes $(7,8)$. Because of this, there has been a growing interest over the last decade in the pleiotropic signaling of nitro-fatty acids $\left(\mathrm{NO}_{2}-\mathrm{FA}\right)$ in numerous disease models that has led to substantial increases in our understanding of the reactive pathways that lead to their formation as well as the complexity of their adsorption, metabolism, and accurate analysis (5). This review will summarize what we know thus far regarding the in vitro and in vivo formation and metabolism of electrophilic $\mathrm{NO}_{2}$-FA.

\section{Nitration of fatty acids}

Although much is known about the enzymatic and non-enzymatic oxidation of unsaturated fatty acids (9-13), fatty acid nitration is less understood. The structural characteristics of the unsaturated fatty acid define the reaction products and their formation is largely dependent on the differing chemical activities between bis-allylic and conjugated diene systems. Two different mechanisms have been proposed for the nitration of polyunsaturated bis-allylic fatty acids (14). The first mechanism is initiated by radical $\left({ }^{\circ} \mathrm{OH},{ }^{\circ} \mathrm{OOH},{ }^{\circ} \mathrm{NO}_{2}\right)$ hydrogen abstraction from a bis-allylic carbon to yield an alkyl radical (Figure 1A-a). This is a common reaction in the formation of other non-enzymatic lipid oxidation products including isoprostanes and hydroperoxides (11). Hydrogen abstraction is followed by double bond rearrangement and the insertion of molecular oxygen $\left(\mathrm{O}_{2}\right)$ to yield a peroxyl radical or insertion of ${ }^{\circ} \mathrm{NO}_{2}$ to generate the non-electrophilic nitroalkane-alkene product (Figure 1A-b) (15). The second mechanism for bis-allylic polyunsaturated fatty acid nitration is the direct addition of ${ }^{\circ} \mathrm{NO}_{2}$ to generate a carbon-centered radical (Figure 1A-c). This radical can be oxidized further with or without ${ }^{\circ} \mathrm{NO}_{2}$ to form the electrophilic nitro-alkene (Figure 1A-e, d, f). Reacting with another molecule of ${ }^{\circ} \mathrm{NO}_{2}$ can form an unstable nitro-nitrito or dinitro compound that will rapidly decompose (releasing $\mathrm{HNO}_{2}$ ) to form an electrophilic nitroalkene (Figure 1A-f) (16). However, biological or physiological conditions seem to be unfavorable for the in vivo generation of electrophilic products from the bis-allyliccontaining fatty acids (i.e. linoleic and arachidonic) through the proposed mechanisms (17). While these $\mathrm{NO}_{2}$-FA species have been observed under a few varying conditions, none have been as extensively characterized and observed as often as nitro-conjugated linoleic acid $\left(\mathrm{NO}_{2}\right.$-cLA). Studies consistently show nitration of cLA as the major $\mathrm{NO}_{2}$-FA formed in murine studies and human clinical trials (17-19).

\section{Endogenous nitro fatty acid formation in animal models}

During the last decade, important advances in the knowledge of in vitro and in vivo lipid nitration have been achieved. In this regard, the first relevant report for the in vivo formation of $\mathrm{NO}_{2}$-FA was in a murine model of focal cardiac ischemia-reperfusion (I/R) (20). In this model, the profile of $\mathrm{NO}_{2}$-FA detected was attributed to nitration of oleic acid $\left(\mathrm{NO}_{2}-\mathrm{OA}\right)$ and linoleic acid $\left(\mathrm{NO}_{2}-\mathrm{LA}\right)$, predominantly the trans- $\mathrm{NO}_{2}-\mathrm{LA}$ isoform. The formation of $\mathrm{NO}_{2}$-FA was a consequence of the reoxygenation-induced tissue damage that involves hypoxia, acidification and the formation of reactive oxygen and nitrogen species; a process that was not observed when myocardial ischemia occurred without reperfusion. Similarly, Nadtochiy et al. demonstrated the presence of $\mathrm{NO}_{2}-\mathrm{FA}$ in the experimental model of 
ischemic preconditioning (IPC) in isolated rat hearts; however, the nitration products differed from the nitrated products obtained in the I/R model. Thus, while a partially characterized trans $-\mathrm{NO}_{2}$-LA was identified in cardiac tissue of the $\mathrm{I} / \mathrm{R}$ model, the cis- $\mathrm{NO}_{2}-$ LA conformation was primarily measured in addition to $\mathrm{NO}_{2}$-OA in the IPC model. Initially, isobaric cis or trans bis-allylic LA (18:2) were designated as the substrate for in vivo nitration reactions; however, using high resolution liquid chromatography mass spectrometry (LC-MS), it was established that nitration preferentially occurs on the isomer of LA characterized by conjugated double bonds (cLA) instead of the bis-allylic methylene group present in LA (17). Thus, initial identification of nitration products were incorrectly identified as cis- and trans-isomers of LA and the retrospective analysis of the original samples from Rudolph's animal model of myocardial focal I/R confirmed the presence of $\mathrm{NO}_{2}$-cLA (17). The conjugated dienes (principally 9-cis, 11-trans-cLA and 10-trans, 12-ciscLA isomers) are the main endogenous targets for in vivo nitration and display reactivity with ${ }^{\circ} \mathrm{NO}_{2} \sim 5$ orders of magnitude higher than the bis-allylic LA (9-cis, 12-cis-LA) (17). Both the bis-allylic and conjugated-diene configuration allows for direct addition of ${ }^{\circ} \mathrm{NO}_{2}$; however, the conjugated system allows for the direct addition at the $\mathrm{C}-9$ or $\mathrm{C}-12$ positions and to a lesser extent at $\mathrm{C}-10$ and $\mathrm{C}-11$ positions, thus generating a delocalized allylic radical that is more stable than its bis-allylic counterpart (21). After ${ }^{\circ} \mathrm{NO}_{2}$ addition (Figure 1B-a), this radical could follow several mechanisms of reaction; i) oxidation of the radical to reform the conjugated diene system with a vinyl $\mathrm{NO}_{2}$ group (Figure 1B-b), ii) the addition of a second ${ }^{-\mathrm{NO}_{2}}$ to the allyl radical intermediate, yielding an unstable dinitro or nitro-nitrito product. The nitrito would undergo rapid decomposition (releasing $\mathrm{HNO}_{2}$ ) to form a vinyl nitro product (Figure 1B-c), and iii) oxidation of the $\mathrm{NO}_{2}$-cLA radical intermediate to a nitro-peroxy followed by reduction of the peroxy to an alkoxy radical mediated by the oxidation of ${ }^{\circ} \mathrm{NO}$ to ${ }^{\circ} \mathrm{NO}_{2}$. This intermediate undergoes another round of reduction to the final product, nitro-hydroxy-OA $\left(\mathrm{NO}_{2}-\mathrm{OH}-\mathrm{OA}\right)$ whereas an environment with higher oxygen tension would promote the formation of nitro-oxo-OA $\left(\mathrm{NO}_{2}\right.$-oxo-OA) (Figure 1Bd). These species expand the profile of fatty acids nitrated by ${ }^{\circ} \mathrm{NO}_{2}$ and increases the diversity of molecules that can impact in the biological function of $\mathrm{NO}_{2}-\mathrm{FA}$ (17). Oxygenated nitro fatty acids have not been well characterized in animal models or human trials and warrant further investigation.

The biological significance of the cLA findings were tested in a series of in vitro and in vivo experiments that involved the generation of the nitrating species ${ }^{\circ} \mathrm{NO}_{2}$ through (a) reaction of ${ }^{\circ} \mathrm{NO}$ with superoxide $\left(\mathrm{O}_{2}{ }^{-}\right)$to yield peroxynitrite $\left(\mathrm{ONOO}^{-}\right)$and its homolytic cleavage products $\left({ }^{\circ} \mathrm{NO}_{2}\right.$ and $\left.{ }^{\circ} \mathrm{OH}\right),(\mathrm{b})$ the one electron oxidation of nitrite $\left(\mathrm{NO}_{2}{ }^{-}\right)$by heme peroxidases (i.e. myeloperoxidase), (c) direct nitration by ${ }^{\circ} \mathrm{NO}_{2}$ gas, and (d) the acidcatalyzed protonation of $\mathrm{NO}_{2}{ }^{-}$to $\mathrm{HNO}_{2}$ followed by its oxidation to ${ }^{\circ} \mathrm{NO}_{2}$ (22). This complex set of reactions demonstrates a variety of different nitrating pathways, yet ${ }^{\circ} \mathrm{NO}_{2}$ is the main intermediate in most of these reactions. Nitration of cLA was achieved in the cellular environment through inflammatory activated macrophages and also in the gastric lumen after oral administration of cLA and $\mathrm{NO}_{2}{ }^{-}$as was reflected by the increase of the endogenous levels in plasma and urine of treated mice $(17,23)$. This mechanism may involve the protonation of $\mathrm{NO}_{2}{ }^{-}$to $\mathrm{HNO}_{2}$ and yields the nitrating ${ }^{\circ} \mathrm{NO}_{2}$ from dinitrogen trioxide $\left(\mathrm{N}_{2} \mathrm{O}_{3}\right)$ and dinitrogen tetroxide $\left(\mathrm{N}_{2} \mathrm{O}_{4}\right)$ homolysis, a process that is favored by the acidic 
condition of gastric compartment leading to nitration of cLA in the gastrointestinal tract (5). These concepts are of significance to other cellular or tissue compartments with acidic $\mathrm{pH}$ that can support $\mathrm{NO}_{2}{ }^{-}$protonation (pKa 3.4) to $\mathrm{HNO}_{2}$ such as lysosomes, ischemic or inflammatory tissue and mitochondria $(17,24)$.

\section{NO in nitration and nitrosation reaction.}

In this complex scenario where $\mathrm{NO}_{2}^{-} /{ }^{\circ} \mathrm{NO}_{2}$ participate extensively in the mechanisms of lipid nitration, it is important to note that ${ }^{\circ} \mathrm{NO}$ does not participate as a direct nitrating species, rather its autoxidation gives rise to the nitrating intermediate ${ }^{\circ} \mathrm{NO}_{2}$ (25). In this context, Vitturi and coworkers showed that ${ }^{\circ} \mathrm{NO}$ was essential for ${ }^{\circ} \mathrm{NO}_{2}$-mediated cLA nitration induced by LPS and INF $\gamma$ macrophage activation. Incubation of activated macrophages with a selective inhibitor of iNOS $(1400 \mathrm{~W})$ in the presence of $\mathrm{NO}_{2}{ }^{-}$abolished cLA nitration revealing that ${ }^{\circ} \mathrm{NO}$ is required for cellular $\mathrm{NO}_{2}{ }^{-}$-dependent nitration (23). Using an experimental strategy with stable isotopes of nitrogen $\left({ }^{15} \mathrm{~N}\right.$ and $\left.{ }^{14} \mathrm{~N}\right)$ the authors described incorporation of ${ }^{15} \mathrm{~N}$ into both ${ }^{15} \mathrm{NO}_{2}$-cLA (nitration) and GS ${ }^{15} \mathrm{NO}$ (glutathione $S$ nitrosation) as a result of a potential mechanism involving the oxidation of ${ }^{15} \mathrm{NO}_{2}{ }^{-}$to ${ }^{15}{ }^{\bullet} \mathrm{NO}_{2}$ (Figure $2 \mathrm{~A}$, reactions $\mathbf{1 - 4}$ ), followed by the reaction of ${ }^{15 \bullet} \mathrm{NO}_{2}$ with ${ }^{14}{ }^{\bullet} \mathrm{NO}$ to generate $\mathrm{N}_{2} \mathrm{O}_{3}$ containing a mix of ${ }^{15} \mathrm{~N}$ and ${ }^{14} \mathrm{~N}$. These are the first findings to show that the formation of symmetrical $\mathrm{N}_{2} \mathrm{O}_{3}$ is possible. The $\operatorname{sym} \mathrm{N}_{2} \mathrm{O}_{3}$ contains two equivalent nitroso groups connected to a central oxygen by identical $\mathrm{N}-\mathrm{O}$ bonds that generate a random distribution of the ${ }^{15} \mathrm{~N}$ or ${ }^{14} \mathrm{~N}$ atom giving rise to ${ }^{14}{ }^{\bullet} \mathrm{NO}$ or ${ }^{15^{\bullet}} \mathrm{NO}$, thus accounting for ${ }^{15}{ }^{\circ} \mathrm{NO}_{2}{ }^{-}$-derived GS- ${ }^{15} \mathrm{NO}$ formation (Figure $2 \mathrm{~B}$ ). In the case of asym $\mathrm{N}_{2} \mathrm{O}_{3}$ the homolytic scission of the N-N bond would regenerate ${ }^{14^{\bullet}} \mathrm{NO}$ and ${ }^{15^{\bullet}} \mathrm{NO}_{2}$ that could not explain the formation GS- ${ }^{15} \mathrm{NO}$ from ${ }^{15} \mathrm{NO}_{2}{ }^{-}$. Thus, two mechanisms can be predicted where $\mathrm{NO}_{2}{ }^{-}$can generate $\operatorname{symN_{2}} \mathrm{O}_{3}$; a) via oxidation of $\mathrm{NO}_{2}{ }^{-}$to ${ }^{\bullet} \mathrm{NO}_{2}$ followed by reaction with ${ }^{\bullet} \mathrm{NO}$, or b) a direct nucleophilic substitution (Figure 2). Taken together, this report confirms previous findings and describes the concept that ${ }^{\circ} \mathrm{NO}$ oxidation plays an important role during in vivo nitration reactions and that nitration reactions are likely to occur anywhere $S$-nitrosation takes place (23).

These findings become relevant at neutral $\mathrm{pH}$ where $\mathrm{NO}_{2}{ }^{-}$cannot generate $\mathrm{HNO}_{2}$ and the formation of nitrating and nitrosating species may be the consequence of metal catalysis. Nitration of cLA was described in a mouse model of acute peritonitis induced by intraperitoneal injection of LPS and isotopically labeled ${ }^{15} \mathrm{~N}^{18} \mathrm{O}_{2}{ }^{-}$. In this study $\mathrm{NO}_{2}$-cLA was formed by endogenously generated ${ }^{14}{ }^{\bullet} \mathrm{NO}_{2}$, but the administration of ${ }^{15} \mathrm{~N}^{18} \mathrm{O}_{2}$ - revealed a dose dependent generation of ${ }^{15} \mathrm{~N}^{18} \mathrm{O}_{2}$-cLA in addition to a scramble of isotopologues $\left({ }^{15} \mathrm{~N}^{18} \mathrm{O}-{ }^{16} \mathrm{O}-\mathrm{cLA},{ }^{14} \mathrm{~N}^{18} \mathrm{O}-{ }^{16} \mathrm{O}-\mathrm{cLA}\right.$ and $\left.{ }^{15} \mathrm{~N}^{16} \mathrm{O}-{ }^{16} \mathrm{O}-\mathrm{cLA}\right)$ indicating that endogenously generated ${ }^{\circ} \mathrm{NO}$ reacts with ${ }^{15} \mathrm{~N}^{18} \mathrm{O}_{2}{ }^{-}$to form $\operatorname{sym} \mathrm{N}_{2} \mathrm{O}_{3}$ in vivo (23). This result highlights a novel role for $\mathrm{NO}_{2}{ }^{\circ} \mathrm{NO}_{2} /{ }^{\circ} \mathrm{NO}$ system as a precursor of $\mathrm{NO}_{2}-\mathrm{FA}$ and nitrosating intermediates, independent of $\mathrm{pH}$ and the presence of metal centers, via the formation of $\operatorname{sym} \mathrm{N}_{2} \mathrm{O}_{3}$ and its stochastic homolysis. A deeper understanding of nitroalkene formation in animal models will aid in the clinical development of $\mathrm{NO}_{2}-\mathrm{FA}$, especially in the context of using dietary supplements of their precursors (i.e. cLA and $\mathrm{NO}_{2}{ }^{-} / \mathrm{NO}_{3}{ }^{-}$) to drive endogenous formation and evoke their signaling potential $(3,5)$. 


\section{$\mathrm{NO}_{2}$-FA formation in humans}

The reactivity, metabolism and distribution of $\mathrm{NO}_{2}$-FA make accurate quantification inherently challenging. Early reports of in vivo levels of $\mathrm{NO}_{2}$-FA described the detection of a $\mathrm{NO}_{2}$-FA profile that included nitrated species of palmitoleic (16:1), oleic (18:1), linoleic (18:2), linolenic (18:3), arachidonic (20:4) and eicosapentaenoic (20:5) acids. Also reported for the first time were quantitative values of free $\mathrm{NO}_{2}-\mathrm{OA}$ upwards of $600 \mathrm{nM}$ and esterified levels that approximated $300 \mathrm{nM}$ in human plasma (26). Several years later these reports were refuted by Tsikas et al. who developed a stable isotope gas chromatography mass spectrometry method to accurately and precisely quantify the $9-\mathrm{NO}_{2}$ - and $10-\mathrm{NO}_{2}$ regioisomers of $\mathrm{NO}_{2}-\mathrm{OA}$ in plasma (27). The levels reported were three orders of magnitude lower than the original report by Baker et al $(27,28)$. Based on follow up studies and further investigation we now know these reports, which quantified sub-nanomolar levels of $\mathrm{NO}_{2}-\mathrm{OA}$ are more accurate. Additionally, numerous studies investigating fatty acid nitration in vitro and in animal models have provided a solid foundation for understanding the nitration of cLA in humans. Under basal metabolic conditions, normal plasma $\mathrm{NO}_{3}{ }^{-}$levels range from 20-40 $\mu \mathrm{M}$ while $\mathrm{NO}_{2}{ }^{-}$levels are substantially lower (50-300 nM) (4). Conversion of $\mathrm{NO}_{3}{ }^{-}$ to $\mathrm{NO}_{2}{ }^{-}$is an insufficient process in mammals as they lack the required nitrate reductases; however, commensal bacteria in the gastrointestinal tract and on body surfaces use $\mathrm{NO}_{3}{ }^{-}$as an alternative electron acceptor during anaerobic respiration to produce ATP (29). Dietary intake of leafy and root vegetables, and herbs account for $60-80 \%$ of total $\mathrm{NO}_{3}{ }^{-}$intake. Other sources include drinking water (15-20\%) and other animal-based products (15-20\%) in which $\mathrm{NO}_{3-}$ and $\mathrm{NO}_{2-}$ are used as preservatives (Figure 3) (4,30-33).

Diet is also the main source of cLA where it is found primarily in dairy products and meat and was originally recognized for its metabolic effects on obesity, body composition, insulin sensitivity, and its association with reduced risk of cardiovascular events (34). cLA is a product of microbiome-promoted isomerization of LA to cLA in humans and animals (35) and rumen also have bacteria with $\Delta^{9}$-desaturase activity capable of metabolizing vaccenic acid (trans-oleic acid) to cLA (36). The predominant dietary isomer is 9-cis, 11-trans-cLA whereas commercial preps made from sunflower oil contain a mixture of 9-cis, 11-trans and 10-trans, 12-cis-cLA (34). Confirmed now by several studies, cLA is the primary endogenous fatty acid to be nitrated at levels 5 orders of magnitude higher than LA to form $\mathrm{NO}_{2}$-cLA (17). $\mathrm{NO}_{2}$-cLA is formed under basal metabolic conditions in humans and rodents. Furthermore, dietary intake or supplement administration can increase $\mathrm{NO}_{2}$-cLA levels most likely due to the mechanisms of nitration described above $(18,37)$. Nitration of conjugated linolenic acid (cLna, punicic acid, 18:3) also occurs and is a primary fatty acid found in pomegranate ( $72 \%)$; however, cLna is absorbed at much lower levels in the diet compared to cLA (38) (Figure 3).

To better understand how diet contributes to $\mathrm{NO}_{2}$-cLA formation and signaling, a pilot study administering oral ${ }^{15} \mathrm{~N}$-labeled $\mathrm{Na}^{15} \mathrm{NO}_{3}{ }^{-}(1 \mathrm{~g})$ and $\mathrm{Na}^{15} \mathrm{NO}_{2}{ }^{-}(20 \mathrm{mg})$ without (Trial 1) and with cLA ( $3 \mathrm{~g}$, Trial 2$)$ was conducted in healthy volunteers $(18,39)$. Volunteers were randomized to either $\mathrm{NO}_{3}{ }^{-}$or $\mathrm{NO}_{2}{ }^{-}$(Trial 1) and after a $\sim 7$ day washout period subjects received the opposite nitrogen oxide. In Trial 2 cLA supplementation was introduced concurrently with $\mathrm{NO}_{3}{ }^{-}$or $\mathrm{NO}_{2}{ }^{-}$supplementation. The endogenous ${ }^{14} \mathrm{NO}_{2}$-cLA and ${ }^{15} \mathrm{NO}_{2}$ - 
cLA derived from the dietary supplementation, along with corresponding metabolites, were measured in plasma and urine by LC-MS. In Trial $1,{ }^{15} \mathrm{NO}_{2}$-cLA was only detected in plasma at the $24 \mathrm{hr}$ time point after ${ }^{15} \mathrm{NO}_{3}{ }^{-}$administration. These results indicated that cLA is rate limiting and its simultaneous presence in the gastric compartment along with $\mathrm{NO}_{3}$ - or $\mathrm{NO}_{2}$ - is required for the formation of $\mathrm{NO}_{2}$-cLA. Hence, in Trial 2, simultaneous cLA supplementation led to the formation of ${ }^{15} \mathrm{NO}_{2}$-cLA after both ${ }^{15} \mathrm{NO}_{3}{ }^{-}$and ${ }^{15} \mathrm{NO}_{2}{ }^{-}$ administration at time points earlier than in Trial $1 .{ }^{15} \mathrm{NO}_{2^{-}}+\mathrm{cLA}$ resulted in detectable, sustained levels of ${ }^{15} \mathrm{NO}_{2}$-cLA from 1 to $6 \mathrm{hr}$ after supplementation where as ${ }^{15} \mathrm{NO}_{2}$-cLA was detected $2 \mathrm{hr}$ after ${ }^{15} \mathrm{NO}_{3}{ }^{-}+\mathrm{cLA}$ supplementation and levels continued to increase over the $24 \mathrm{hr}$ period. Formation of ${ }^{15} \mathrm{NO}_{2}$-cLA after ${ }^{15} \mathrm{NO}_{2}{ }^{-}+\mathrm{cLA}$ supplementation tracked with peak levels of free cLA in plasma. Urinary cysteine adducts of ${ }^{14} \mathrm{NO}_{2}$-cLA, ${ }^{15} \mathrm{NO}_{2}$ cLA and $\beta$-oxidation metabolites were also measured, thus confirming the electrophilic reactivity of the parent molecules and metabolites (18).

In this study the clinical responses were investigated to explore the impact of dietary lipid on nitrogen oxide metabolism and cardiovascular responses. Dietary supplementation of ${ }^{15} \mathrm{NO}_{3}{ }^{-}$and ${ }^{15} \mathrm{NO}_{2}{ }^{-}$support ${ }^{15} \mathrm{NO}$ formation as measured by electroparamagnetic resonance spectroscopy detection of ${ }^{15} \mathrm{NO}$-deoxyhemoglobin complexes. ${ }^{15}{ }^{\circ} \mathrm{NO}$ formation resulted in decreased systolic and mean arterial blood pressures and inhibited platelet function in Trial 1. Co-administration of cLA in Trial 2 reduced plasma $\mathrm{NO}_{3}{ }^{-}$and $\mathrm{NO}_{2}{ }^{-}$ levels, decreased ${ }^{15{ }^{\circ}} \mathrm{NO}$-deoxyhemoglobin formation, $\mathrm{NO}_{2}{ }^{-}$inhibition of platelet activation, and the vasodilatory properties of $\mathrm{NO}_{2}{ }^{-}$while enhancing the formation of ${ }^{15} \mathrm{NO}_{2}$-cLA. Thus the co-administration of the dietary supplement, cLA, significantly redirects cardiac responses attributed to $\mathrm{NO}_{2}-{ }^{\circ} \mathrm{NO}$ to alternate pathways (39).

The discovery of endogenous $\mathrm{NO}_{2}$-cLA formation in humans under basal conditions and its elevated formation and signaling during inflammation and metabolic stress expands the pharmacokinetics and scope of ${ }^{\circ} \mathrm{NO}$ signaling beyond guanylate cyclase-dependent cGMP production. Although mechanisms of $\mathrm{NO}_{2}$-cLA formation and signaling have been investigated in vitro and in animal models and to some extent now in humans, there is still much we do not know. Further studies are warranted to investigate how diet, precursor supplementation, and the microbiome influence $\mathrm{NO}_{2}$-cLA formation and signaling compared to the administration of the pre-formed $\mathrm{NO}_{2}$-FA as the chemistry and pathway targets of $\mathrm{NO}_{3}{ }^{-} / \mathrm{NO}_{2}{ }^{-}+$cLA and $\mathrm{NO}_{2}$-cLA will greatly vary.

\section{$\mathrm{NO}_{2}$-FA metabolism and distribution}

The formation, metabolism, distribution and excretion of $\mathrm{NO}_{2}$-FA comprise a metabolic network capable of regulating steady state levels and signaling activity of these molecules under both basal and pathological conditions (Figure 4). The detection and measurement of $\mathrm{NO}_{2}$-FA and metabolites is inherently challenging because they form reversible covalent adducts with nucleophilic amino acids in proteins and cysteines in thiol containing molecules, such as GSH. Additionally as fatty acid species, they bind fatty acid binding pockets of carrier proteins like albumin (40) and participate in normal lipid metabolism and transport as they undergo saturation, $\beta$-oxidation, and are esterified into complex lipids (4144). A complete knowledge of their metabolism will be required to fully understand their 
role as novel therapeutics for a variety of inflammatory diseases and recent studies are beginning to unravel their pharmacokinetic profile.

Similar to other fatty acids, saturation and $\beta$-oxidation products as well as $\mathrm{NO}_{2}$-FACoenzyme A conjugates ( $\mathrm{NO}_{2}$-FA-CoA) have been detected and well characterized by LCMS/MS (44). Many PK studies have utilized $\mathrm{NO}_{2}-\mathrm{OA}$ as a model $\mathrm{NO}_{2}$-FA since it has one double bond, thus making metabolism easier to characterize; although, increasing evidence suggests $\mathrm{NO}_{2}$-cLA metabolism follows a very similar pattern. The predominant free fatty acid species resulting from $\mathrm{NO}_{2}-\mathrm{OA}$ metabolism is nitro-stearic acid $\left(\mathrm{NO}_{2}-\mathrm{SA}\right)$ (44). $\mathrm{NO}_{2-}$ $\mathrm{SA}$ is a non-electrophilic nitroalkane formed from the saturation of the electrophilic double bond of $\mathrm{NO}_{2}$-OA by prostaglandin reductase 1 (PTGR1) (45). $\mathrm{NO}_{2}$-OA and $\mathrm{NO}_{2}$-SA can undergo several rounds of $\beta$-oxidation to form dinor (C16), tetranor (C14) and hexanor (C12) species. Similar metabolites have been described for $\mathrm{NO}_{2}$-cLA and these species have been detected in animal models and human plasma and urine under basal conditions and after supplementation (37). Other oxidized and nitrated products (e.g. nitro-nitrate, hydroxyl- $\mathrm{NO}_{2}-\mathrm{FA}$ ) have been observed in various studies, but have not been explored in detail (46-48) (Figure 4).

A recent study gave an even more detailed report of $\mathrm{NO}_{2}$-FA metabolism and discovered taurine and sulfo- adducts along with $\omega$-oxidation products as evidenced by dicarboxylic metabolites of reduced and electrophilic $\mathrm{NO}_{2}$-FA (49). Many of these products are found in both rodents and humans. $\mathrm{NO}_{2}$-FA readily form adducts with $\mathrm{GSH}$ and these adducts are exported from cells by multi-drug resistance transporters $(50,51)$ and metabolites of GSH adduction are detected in urine as $\mathrm{NO}_{2}$-FA adducts of $\mathrm{N}$-acetylcysteine and cysteine $(37,49)$. These products are in equilibrium with free $\mathrm{NO}_{2}$-FA and corresponding metabolites in urine and can be readily displaced by thiol reaction with mercury chloride, increasing the free $\mathrm{NO}_{2}$-FA pool by an order of magnitude (37) (Figure 4).

The intricacies of NO2-FA metabolism and distribution are slowly being unraveled, as the incorporation of $\mathrm{NO}_{2}$-FA into complex lipids in cells and in vivo have been reported (Figure 4). The formation of $\mathrm{NO}_{2}$-FA-containing triglycerides (TG) have been analyzed during in vitro acidic gastric digestion of $\mathrm{TG}$ and in adipocytes and rat plasma after $\mathrm{NO}_{2}-\mathrm{OA}$ supplementation (41) whereas endogenously formed $\mathrm{NO}_{2}$-FA and nitro-oxidized-containing phospholipids were detected in isolated cardiac mitochondria and cardiomyoblasts in a type 1 diabetes mellitus animal model (48). These data demonstrate that $\mathrm{NO}_{2}$-FA-containing complex lipids can be generated after gastric digestion and inflammatory conditions.

An exhaustive quantitative body distribution analysis of radiolabeled $\left[{ }^{14} \mathrm{C}\right]-10-\mathrm{NO}_{2}$-OA has been reported after oral administration in rats. Upon absorption, radioactivity was mainly distributed in kidney, liver, lungs, and heart, while long lasting accumulation was detected in brown and white adipose tissue over two weeks (42). However, the radioactivity measured in tissues by autoradiography could result from the $\left[{ }^{14} \mathrm{C}\right]-10-\mathrm{NO}_{2}$-OA or its ${ }^{14} \mathrm{C}$-containing metabolites. To better understand $\mathrm{NO}_{2}-\mathrm{OA}$ metabolism and incorporation profiling into complex lipids, fractionated lipid classes of adipocytes and murine adipose tissue supplemented with $\mathrm{NO}_{2}$-OA were hydrolyzed and analyzed by HPLC-MS/MS. Interestingly, it was demonstrated that non-electrophilic $\mathrm{NO}_{2}-\mathrm{OA}$ metabolites, such as $\mathrm{NO}_{2}-\mathrm{SA}$, were 
preferentially esterified into TGs, while $\mathrm{NO}_{2}-\mathrm{OA}$ was incorporated into monoglycerides (MG) and diglycerides (DG) to a larger extent. This trend was further confirmed by supplementing adipocytes with $\mathrm{NO}_{2}$-cLA, $\mathrm{NO}_{2}$ - $\mathrm{LnA}$ and $\mathrm{NO}_{2}$-SA. In this regard, the differential incorporation into $\mathrm{MG}+\mathrm{DG}$ and $\mathrm{TG}$ of $\mathrm{NO}_{2}-\mathrm{FA}$ may be a consequence of their cellular availability, trafficking, and metabolism. In fact, the free intracellular pool of unsaturated $\mathrm{NO}_{2}$-FA is influenced by the electrophilic reactivity toward GSH and the formation of $\mathrm{NO}_{2}$-FA-GSH adducts, which are exported extracellularly by the multi-drug resistance proteins $(50,52)$. In addition, intracellular $\mathrm{NO}_{2}$-FA are metabolized by tissuespecific PTGR1 and long-chain acyl-CoA synthetase (ACSL) isoforms, generating saturated $\mathrm{NO}_{2}$-FA and $\mathrm{NO}_{2}$-FA-CoA species, respectively. Of note, ACSL isoforms have shown FA preferences (53) and could differentially esterify $\mathrm{NO}_{2}$-FA to form the CoA derivatives. Furthermore, the resultant $\mathrm{NO}_{2}$-FA-CoA may be preferentially used by different enzymes to generate phospholipids and glycerolipids. Then, the esterification of unsaturated $\mathrm{NO}_{2}$-FA into $\mathrm{MG}+\mathrm{DG}$ fractions may generate a depot of potentially bioactive lipids, which could store and release electrophilic signaling mediators following an inflammatory response. Instead, the incorporation of saturated $\mathrm{NO}_{2}$-FA into TG fractions confirms their role as depot of inactive non-electrophilic metabolites. Esterified $\mathrm{NO}_{2}-\mathrm{OA}$ was $\sim 18 \times$ more abundant in $\mathrm{MG}+\mathrm{DG}$ vs. TG. The profile for $\mathrm{NO}_{2}$-cLA was similar to $\mathrm{NO}_{2}-\mathrm{OA}$; however, overall esterification was 10-20\% lower. Overall there were lower levels of incorporation into phospholipids compared to glycerolipids (41). These data demonstrate that $\mathrm{NO}_{2}-\mathrm{FA}$ and metabolites are distributed and incorporated into complex lipids, which can release electrophilic species after lipase hydrolysis and be delivered to remote tissue as lipoproteins, thus modulating cell homeostasis and tissue signaling.

\section{Conclusions and Future Studies}

The mechanisms of fatty acid nitration in vivo remain unclear; however, during recent years important advances have been made to elucidate the molecular intermediaries involved in nitration, its molecular targets and the resulting reaction products. Confirmation of cLA as the primary endogenous $\mathrm{NO}_{2}-\mathrm{FA}$, correct measurement of free endogenous $\mathrm{NO}_{2}-\mathrm{OA}$ as well as new analyses of $\mathrm{NO}_{2}$-FA incorporation into complex lipids have helped shape the overall picture of $\mathrm{NO}_{2}$-FA formation and have provided better insight into the pharmacokinetics and pharmacodynamics of these pleiotropic anti-inflammatory therapies. Analysis of excreted radioactivity and metabolites in urine showed that $10-\mathrm{NO}_{2}-\mathrm{OA}$ is extensively absorbed and rapidly metabolized within $24 \mathrm{hr}$ (49). Future studies focused on $\mathrm{NO}_{2}$-FA intestinal absorption and the evaluation of hepatic (first-pass) metabolism is required as they need to solve the discrepancy between initial reports of $\mathrm{NO}_{2}$-OA bioavailability ( $6 \%$ ) (unpublished data) and the $35 \%$ urinary recovery reported in the $\left[{ }^{14} \mathrm{C}\right]-\mathrm{NO}_{2}-\mathrm{OA}$ rat study (49). It may be that a significant portion of $\mathrm{NO}_{2}-\mathrm{FA}$ is stored in complex lipids and distributed throughout various tissues. These studies along with further characterization of novel $\mathrm{NO}_{2}-\mathrm{FA}$ metabolites and the investigation of next generation $\mathrm{NO}_{2}$-FA derivatives (54) as therapeutics will continue to expand our knowledge of the formation and metabolism of this pleiotropic class of therapeutic signaling molecules. 


\section{Acknowledgements.}

This work was supported by funding from the following sources: R21AI122071 (SGW), F31HL142171 (GJB), Fondazione Ri.Med, Italy (MAF) and Fondo para la Investigación Cientifica y Tecnológica (FONCyT) and Prestamo BID Proyetcto de Investigación en Cienceia y Tecnologia (PICT) grant 2013-3288 (GB).

\section{References}

1. Bryan NS (2011) Application of nitric oxide in drug discovery and development. Expert Opin Drug Discov 6, 1139-1154 [PubMed: 22646983]

2. Bryan NS, Rassaf T, Maloney RE, Rodriguez CM, Saijo F, Rodriguez JR, and Feelisch M (2004) Cellular targets and mechanisms of nitros(yl)ation: an insight into their nature and kinetics in vivo. Proc Natl Acad Sci U S A 101, 4308-4313 [PubMed: 15014175]

3. Lundberg JO, Gladwin MT, Ahluwalia A, Benjamin N, Bryan NS, Butler A, Cabrales P, Fago A, Feelisch M, Ford PC, Freeman BA, Frenneaux M, Friedman J, Kelm M, Kevil CG, Kim-Shapiro DB, Kozlov AV, Lancaster JR, Jr., Lefer DJ, McColl K, McCurry K, Patel RP, Petersson J, Rassaf T, Reutov VP, Richter-Addo GB, Schechter A, Shiva S, Tsuchiya K, van Faassen EE, Webb AJ, Zuckerbraun BS, Zweier JL, and Weitzberg E (2009) Nitrate and nitrite in biology, nutrition and therapeutics. Nat Chem Biol 5, 865-869 [PubMed: 19915529]

4. Weitzberg E, and Lundberg JO (2013) Novel aspects of dietary nitrate and human health. Annu Rev Nutr 33, 129-159 [PubMed: 23642194]

5. Schopfer F, Cipollina C and Freeman BA. (2011) Formation and signaling actions of electrophilic lipids. Chem Rev 111, 5997-6021 [PubMed: 21928855]

6. Delmastro-Greenwood M, Freeman BA, and Wendell SG (2014) Redox-dependent antiinflammatory signaling actions of unsaturated fatty acids. Annual review of physiology 76, 79-105

7. Batthyany C, Schopfer FJ, Baker PR, Duran R, Baker LM, Huang Y, Cervenansky C, Branchaud BP, and Freeman BA (2006) Reversible post-translational modification of proteins by nitrated fatty acids in vivo. J. Biol. Chem 281, 20450-20463 [PubMed: 16682416]

8. Turell L, Vitturi DA, Coitino EL, Lebrato L, Moller MN, Sagasti C, Salvatore SR, Woodcock SR, Alvarez B, and Schopfer FJ (2017) The Chemical Basis of Thiol Addition to Nitro-conjugated Linoleic Acid, a Protective Cell-signaling Lipid. J Biol Chem 292, 1145-1159 [PubMed: 27923813]

9. Milne GL, Yin H, Hardy KD, Davies SS, and Roberts LJ, 2nd. (2011) Isoprostane generation and function. Chem Rev 111, 5973-5996 [PubMed: 21848345]

10. Capdevila JH, Falck JR, and Estabrook RW (1992) Cytochrome P450 and the arachidonate cascade. FASEB J 6, 731-736 [PubMed: 1537463]

11. Yin H, Xu L, and Porter NA (2011) Free radical lipid peroxidation: mechanisms and analysis. Chem Rev 111, 5944-5972 [PubMed: 21861450]

12. Smith WL, Urade Y, and Jakobsson PJ (2011) Enzymes of the cyclooxygenase pathways of prostanoid biosynthesis. Chem Rev 111, 5821-5865 [PubMed: 21942677]

13. Haeggstrom JZ, and Funk CD (2011) Lipoxygenase and leukotriene pathways: biochemistry, biology, and roles in disease. Chem Rev 111, 5866-5898 [PubMed: 21936577]

14. Woodcock SR, Bonacci G, Gelhaus SL, and Schopfer FJ (2013) Nitrated fatty acids: synthesis and measurement. Free Radic Biol Med 59, 14-26 [PubMed: 23200809]

15. Pryor WA, Lightsey JW, and Church DF (1982) Reaction of Nitrogen Dioxide with Alkenes and Polyunsaturated Fatty Acids: Addition and Hydrogen Abstraction Mechanisms. J Am Chem Soc 104, 6685-6692

16. d'Ischia M, Napolitano A, Manini P, and Panzella L (2011) Secondary targets of nitrite-derived reactive nitrogen species: nitrosation/nitration pathways, antioxidant defense mechanisms and toxicological implications. Chem Res Toxicol 24, 2071-2092 [PubMed: 21923154]

17. Bonacci G, Baker PR, Salvatore SR, Shores D, Khoo NK, Koenitzer JR, Vitturi DA, Woodcock SR, Golin-Bisello F, Cole MP, Watkins S, St Croix C, Batthyany CI, Freeman BA, and Schopfer FJ (2012) Conjugated linoleic acid is a preferential substrate for fatty acid nitration. J Biol Chem 287, 44071-44082 [PubMed: 23144452] 
18. Meghan Delmastro-Greenwood KSH, Vitturia Dario A., Salvatore Sonia R., Grimes George, Potti Gopal, Shiva Sruti, Schopfer Francisco J., Gladwin Mark T., Freeman Bruce A.,, Wendell Stacy Gelhaus (2015) Nitrite and nitrate-dependent generation of anti-inflammatory fatty acid nitroalkenes. Free Radic Biol Med 89, 333-341 [PubMed: 26385079]

19. Villacorta L, Minarrieta L, Salvatore SR, Khoo NK, Rom O, Gao Z, Berman RC, Jobbagy S, Li L, Woodcock SR, Chen YE, Freeman BA, Ferreira AM, Schopfer FJ, and Vitturi DA (2018) In situ generation, metabolism and immunomodulatory signaling actions of nitro-conjugated linoleic acid in a murine model of inflammation. Redox Biol 15, 522-531 [PubMed: 29413964]

20. Rudolph V, Rudolph TK, Schopfer FJ, Bonacci G, Woodcock SR, Cole MP, Baker PR, Ramani R, and Freeman BA (2010) Endogenous generation and protective effects of nitro-fatty acids in a murine model of focal cardiac ischaemia and reperfusion. Cardiovasc Res 85, 155-166 [PubMed: 19666678]

21. Bonacci G, Asciutto EK, Woodcock SR, Salvatore SR, Freeman BA, and Schopfer FJ (2011) Gasphase fragmentation analysis of nitro fatty acids. J. Am. Soc. Mass Spectrom

22. O’Donnell VB, Eiserich JP, Chumley PH, Jablonsky MJ, Krishna NR, Kirk M, Barnes S, DarleyUsmar VM, and Freeman BA (1999) Nitration of unsaturated fatty acids by nitric oxide-derived reactive nitrogen species peroxynitrite, nitrous acid, nitrogen dioxide, and nitronium ion. Chem Res Toxicol 12, 83-92 [PubMed: 9894022]

23. Vitturi DA, Minarrieta L, Salvatore Sonia R., Postlethwait Edward M., Fazzari Marco, Ferrer-Sueta Gerardo, Lancaster Jack R., Freeman Bruce A., and Schopfer Francisco J.. (2015) Convergence of Biological Nitration and Nitrosation Reactions via Symmetrical Nitrous Anhydride (N2O3). Nature Chemical Biology

24. Rudolph V, Rudolph TK, Schopfer FJ, Bonacci G, Woodcock SR, Cole MP, Baker PR, Ramani R, and Freeman BA (2009) Endogenous generation and protective effects of nitro-fatty acids in a murine model of focal cardiac ischaemia and reperfusion. Cardiovasc Res

25. Wink DA, Darbyshire JF, Nims RW, Saavedra JE, and Ford PC (1993) Reactions of the bioregulatory agent nitric oxide in oxygenated aqueous media: determination of the kinetics for oxidation and nitrosation by intermediates generated in the $\mathrm{NO} / \mathrm{O} 2$ reaction. Chemical Research in Toxicology 6, 23-27 [PubMed: 8448345]

26. Baker PR, Lin Y, Schopfer FJ, Woodcock SR, Groeger AL, Batthyany C, Sweeney S, Long MH, Iles KE, Baker LM, Branchaud BP, Chen YE, and Freeman BA (2005) Fatty acid transduction of nitric oxide signaling: multiple nitrated unsaturated fatty acid derivatives exist in human blood and urine and serve as endogenous peroxisome proliferator-activated receptor ligands. J. Biol. Chem 280, 42464-42475 [PubMed: 16227625]

27. Tsikas D, Zoerner A, Mitschke A, Homsi Y, Gutzki FM, and Jordan J (2009) Specific GC-MS/MS stable-isotope dilution methodology for free 9- and 10-nitro-oleic acid in human plasma challenges previous LC-MS/MS reports. J Chromatogr B Analyt Technol Biomed Life Sci 877, 2895-2908

28. Tsikas D, Zoerner AA, Mitschke A, and Gutzki FM (2009) Nitro-fatty acids occur in human plasma in the picomolar range: a targeted nitro-lipidomics GC-MS/MS study. Lipids 44, 855-865 [PubMed: 19701657]

29. Moreno-Vivian C, Cabello P, Martinez-Luque M, Blasco R, and Castillo F (1999) Prokaryotic nitrate reduction: molecular properties and functional distinction among bacterial nitrate reductases. J Bacteriol 181, 6573-6584 [PubMed: 10542156]

30. Lundberg JO, and Weitzberg E (2009) NO generation from inorganic nitrate and nitrite: Role in physiology, nutrition and therapeutics. Arch Pharm Res 32, 1119-1126 [PubMed: 19727604]

31. Lundberg JO, Weitzberg E, Cole JA, and Benjamin N (2004) Nitrate, bacteria and human health. Nat Rev Microbiol 2, 593-602 [PubMed: 15197394]

32. Lundberg JO, Weitzberg E, and Gladwin MT (2008) The nitrate-nitrite-nitric oxide pathway in physiology and therapeutics. Nat Rev Drug Discov 7, 156-167 [PubMed: 18167491]

33. van Faassen EE, Bahrami S, Feelisch M, Hogg N, Kelm M, Kim-Shapiro DB, Kozlov AV, Li H, Lundberg JO, Mason R, Nohl H, Rassaf T, Samouilov A, Slama-Schwok A, Shiva S, Vanin AF, Weitzberg E, Zweier J, and Gladwin MT (2009) Nitrite as regulator of hypoxic signaling in mammalian physiology. Med Res Rev 29, 683-741 [PubMed: 19219851] 
34. Shen W, and McIntosh MK (2016) Nutrient Regulation: Conjugated Linoleic Acid's Inflammatory and Browning Properties in Adipose Tissue. Annu Rev Nutr 36, 183-210 [PubMed: 27431366]

35. Liavonchanka A, Rudolph MG, Tittmann K, Hamberg M, and Feussner I (2009) On the mechanism of a polyunsaturated fatty acid double bond isomerase from Propionibacterium acnes. J Biol Chem 284, 8005-8012 [PubMed: 19164287]

36. Corl BA, Baumgard LH, Dwyer DA, Griinari JM, Phillips BS, and Bauman DE (2001) The role of Delta(9)-desaturase in the production of cis-9, trans-11 CLA. J Nutr Biochem 12, 622-630 [PubMed: 12031255]

37. Salvatore SR, Vitturi DA, Baker PR, Bonacci G, Koenitzer JR, Woodcock SR, Freeman BA, and Schopfer FJ (2013) Characterization and quantification of endogenous fatty acid nitroalkene metabolites in human urine. Journal of lipid research 54, 1998-2009 [PubMed: 23620137]

38. Suzuki R, Noguchi R, Ota T, Abe M, Miyashita K, and Kawada T (2001) Cytotoxic effect of conjugated trienoic fatty acids on mouse tumor and human monocytic leukemia cells. Lipids 36 , 477-482 [PubMed: 11432460]

39. Hughan KS, Wendell SG, Delmastro-Greenwood M, Helbling N, Corey C, Bellavia L, Potti G, Grimes G, Goodpaster B, Kim-Shapiro DB, Shiva S, Freeman BA, and Gladwin MT (2017) Conjugated Linoleic Acid Modulates Clinical Responses to Oral Nitrite and Nitrate. Hypertension

40. Spector AA (1975) Fatty acid binding to plasma albumin. Journal of lipid research 16, 165-179 [PubMed: 236351]

41. Fazzari M, Khoo N, Woodcock SR, Li L, Freeman BA, and Schopfer FJ (2015) Generation and esterification of electrophilic fatty acid nitroalkenes in triacylglycerides. Free Radic Biol Med 87, 113-124 [PubMed: 26066303]

42. Fazzari M, Khoo NK, Woodcock SR, Jorkasky DK, Li L, Schopfer FJ, and Freeman BA (2017) Nitro-fatty acid pharmacokinetics in the adipose tissue compartment. J Lipid Res 58, 375-385 [PubMed: 27913584]

43. Fazzari M, Trostchansky A, Schopfer FJ, Salvatore SR, Sanchez-Calvo B, Vitturi D, Valderrama R, Barroso JB, Radi R, Freeman BA, and Rubbo H (2014) Olives and olive oil are sources of electrophilic fatty acid nitroalkenes. PLoS One 9, e84884 [PubMed: 24454759]

44. Rudolph V, Schopfer FJ, Khoo NK, Rudolph TK, Cole MP, Woodcock SR, Bonacci G, Groeger AL, Golin-Bisello F, Chen CS, Baker PR, and Freeman BA (2009) Nitro-fatty acid metabolome: saturation, desaturation, beta-oxidation, and protein adduction. J. Biol. Chem 284, 1461-1473 [PubMed: 19015269]

45. Vitturi DA, Chen CS, Woodcock SR, Salvatore SR, Bonacci G, Koenitzer JR, Stewart NA, Wakabayashi N, Kensler TW, Freeman BA, and Schopfer FJ (2013) Modulation of nitro-fatty acid signaling: prostaglandin reductase-1 is a nitroalkene reductase. J Biol Chem 288, 25626-25637 [PubMed: 23878198]

46. Baker PR, Lin Y, Schopfer FJ, Woodcock SR, Groeger AL, Batthyany C, Sweeney S, Long MH, Iles KE, Baker LM, Branchaud BP, Chen YE, and Freeman BA (2005) Fatty acid transduction of nitric oxide signaling: multiple nitrated unsaturated fatty acid derivatives exist in human blood and urine and serve as endogenous peroxisome proliferator-activated receptor ligands. J Biol Chem 280, 42464-42475 [PubMed: 16227625]

47. Baker PR, Schopfer FJ, Sweeney S, and Freeman BA (2004) Red cell membrane and plasma linoleic acid nitration products: synthesis, clinical identification, and quantitation. Proceedings of the National Academy of Sciences of the United States of America 101, 11577-11582 [PubMed: 15273286]

48. Melo T, Domingues P, Ferreira R, Milic I, Fedorova M, Santos SM, Segundo MA, and Domingues MR (2016) Recent Advances on Mass Spectrometry Analysis of Nitrated Phospholipids. Analytical chemistry 88, 2622-2629 [PubMed: 26814598]

49. Salvatore SR, Vitturi DA, Fazzari M, Jorkasky DK, and Schopfer FJ (2017) Evaluation of 10-Nitro Oleic Acid Bio-Elimination in Rats and Humans. Sci Rep 7, 39900 [PubMed: 28054588]

50. Woodcock CC, Huang Y, Woodcock SR, Salvatore SR, Singh B, Golin-Bisello F, Davidson NE, Neumann CA, Freeman BA, and Wendell SG (2018) Nitro-fatty acid inhibition of triple-negative breast cancer cell viability, migration, invasion, and tumor growth. J Biol Chem 293, 1120-1137 [PubMed: 29158255] 
51. Baker LM, Baker PR, Golin-Bisello F, Schopfer FJ, Fink M, Woodcock SR, Branchaud BP, Radi R, and Freeman BA (2007) Nitro-fatty acid reaction with glutathione and cysteine. Kinetic analysis of thiol alkylation by a Michael addition reaction. J. Biol. Chem 282, 31085-31093 [PubMed: 17720974]

52. Bates DJ, Lively MO, Gorczynski MJ, King SB, Townsend AJ, and Morrow CS (2009) Noncatalytic interactions between glutathione $S$-transferases and nitroalkene fatty acids modulate nitroalkene-mediated activation of peroxisomal proliferator-activated receptor gamma. Biochemistry 48, 4159-4169 [PubMed: 19358561]

53. Golej DL, Askari B, Kramer F, Barnhart S, Vivekanandan-Giri A, Pennathur S, and Bornfeldt KE (2011) Long-chain acyl-CoA synthetase 4 modulates prostaglandin E(2) release from human arterial smooth muscle cells. Journal of lipid research 52, 782-793 [PubMed: 21242590]

54. Khoo NKH, Li L, Salvatore SR, Schopfer FJ, and Freeman BA (2018) Electrophilic fatty acid nitroalkenes regulate Nrf2 and NF-kappaB signaling:A medicinal chemistry investigation of structure-function relationships. Sci Rep 8, 2295 [PubMed: 29396403] 


\section{Highlights}

- $\quad$ Nitro-Fatty Acid $\left(\mathrm{NO}_{2}-\mathrm{FA}\right)$ formation is highly dependent on environmental factors including $\mathrm{pH}$, oxygen tension and the presence of reactive species.

- $\quad \mathrm{NO}_{2}$-cLA is the most abundant, endogenous $\mathrm{NO}_{2}$-FA.

- $\quad \mathrm{NO}_{2}$-cLA is generated during metabolism and under conditions of inflammatory stress.

- Absolute measurement of $\mathrm{NO}_{2}-\mathrm{FA}$ is complicated by protein adduction, metabolism (reduction, $\beta$-oxidation, conjugation), and incorporation into complex lipids. 


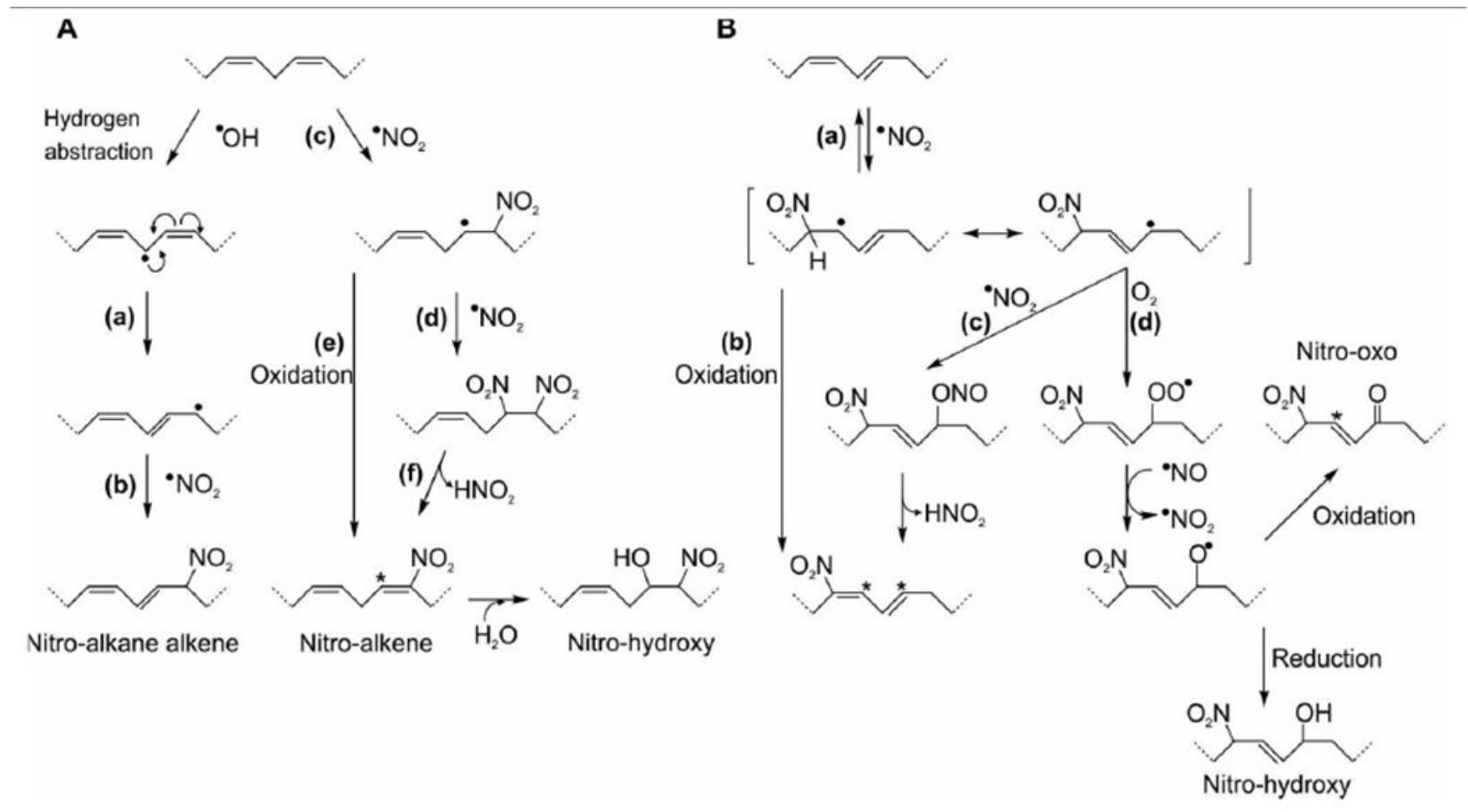

Figure 1: Proposed mechanisms of $\mathrm{NO}_{2}$-FA formation.

(A) $\mathrm{NO}_{2}$-FA formation from bis-allylic unsaturated fatty acids. (B) Nitration of conjugated linoleic acid. Asterisk indicate reactive electrophilic carbons. 
A

$$
\begin{aligned}
& { }^{\circ} \mathrm{NO}+\mathrm{O}_{2} \rightleftarrows \mathrm{ONOO}+{ }^{\circ} \mathrm{NO} \longrightarrow \mathrm{N}_{2} \mathrm{O}_{4} \\
& \mathrm{~N}_{2} \mathrm{O}_{4} \longleftrightarrow 2^{\circ} \mathrm{NO}_{2} \\
& \cdot \mathrm{NO}_{2}+{ }^{\bullet} \mathrm{NO} \rightleftarrows \mathrm{N}_{2} \mathrm{O}_{3} \\
& \mathrm{~N}_{2} \mathrm{O}_{3}+\mathrm{H}_{2} \mathrm{O} \rightleftarrows 2 \mathrm{NO}_{2}+2 \mathrm{H}^{+}
\end{aligned}
$$

B

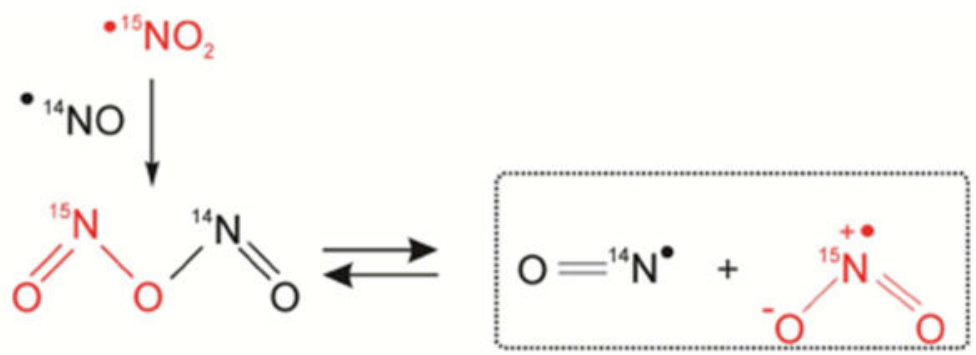

${ }^{14} \mathrm{NO}_{2}-\mathrm{CLA}+\mathrm{GS}-{ }^{15} \mathrm{NO}$
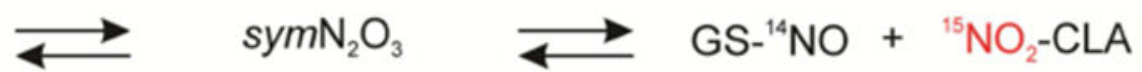

Figure 2: Generation of $\operatorname{symN}_{2} \mathrm{O}_{3}$.

(A) From $\mathrm{NO}_{2}{ }^{-}$oxidation to form ${ }^{\bullet} \mathrm{NO}_{2}$ followed by reaction with $\mathbf{~} \mathrm{NO}$ (B) or direct nucleophilic substitution. 


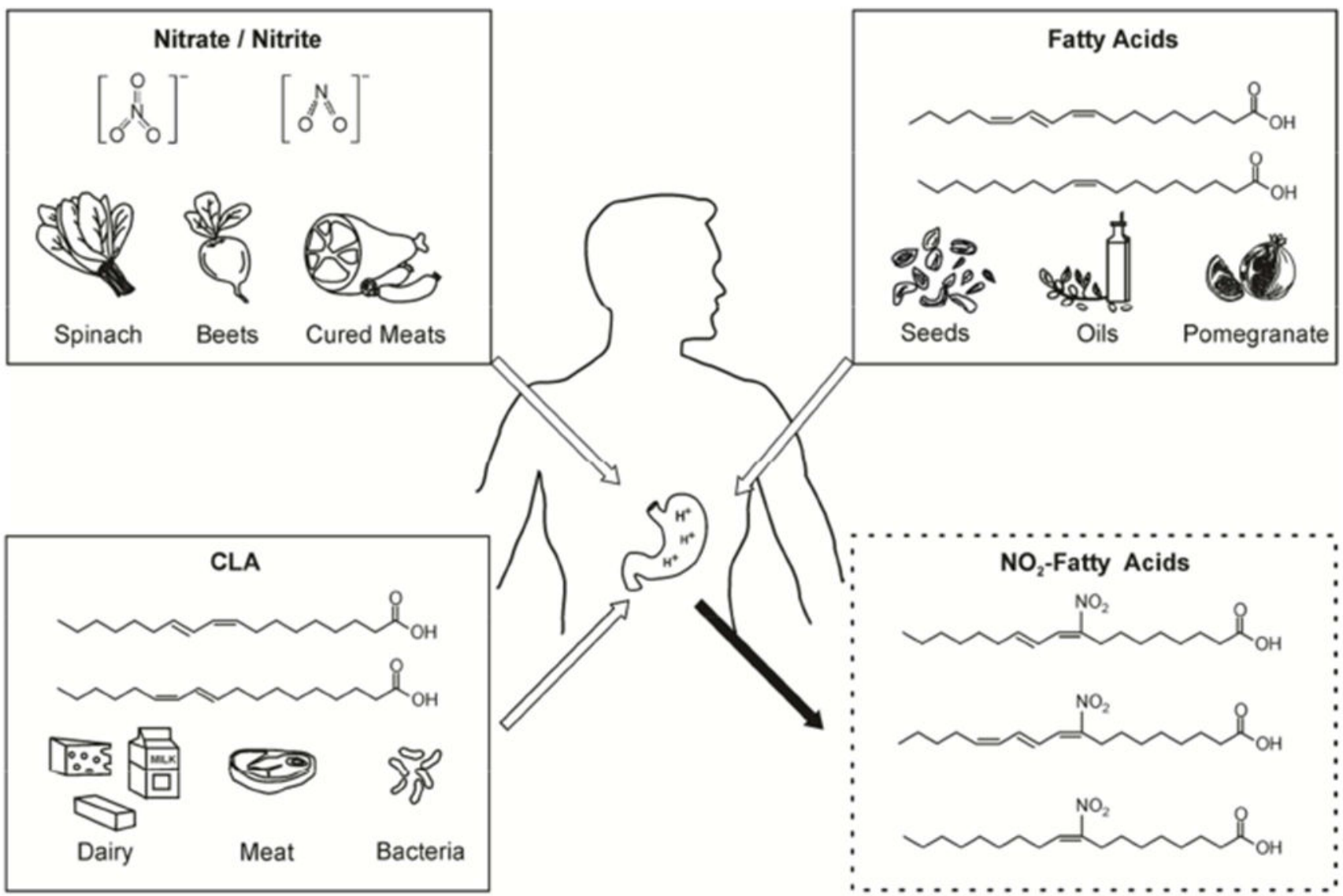

Figure 3: Dietary intake alters endogenous $\mathrm{NO}_{2}$-FA formation.

Nitrate $\left(\mathrm{NO}_{3}{ }^{-}\right)$, nitrite $\left(\mathrm{NO}_{2}^{-}\right)$and fatty acids such as oleic (OA, 18:1), conjugated linoleic (cLA, 18:2) and linolenic (cLnA,18:3) acid are found in dietary sources including vegetables, seeds and oils, meat and dairy. Further metabolism of $\mathrm{NO}_{3}{ }^{-}$and $\mathrm{NO}_{2}{ }^{-}$results in multiple nitrogen oxides including nitrogen dioxide $\left({ }^{\circ} \mathrm{NO}_{2}\right)$. Fatty acids most susceptible to nitration by ${ }^{\bullet} \mathrm{NO}_{2}$ are those with a conjugated diene structure. Due to its abundance in the diet, cLA is the predominant endogenous fatty acid that is nitrated to form $\mathrm{NO}_{2}$-cLA. 


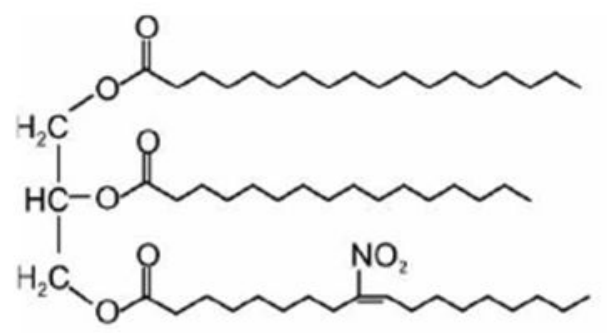
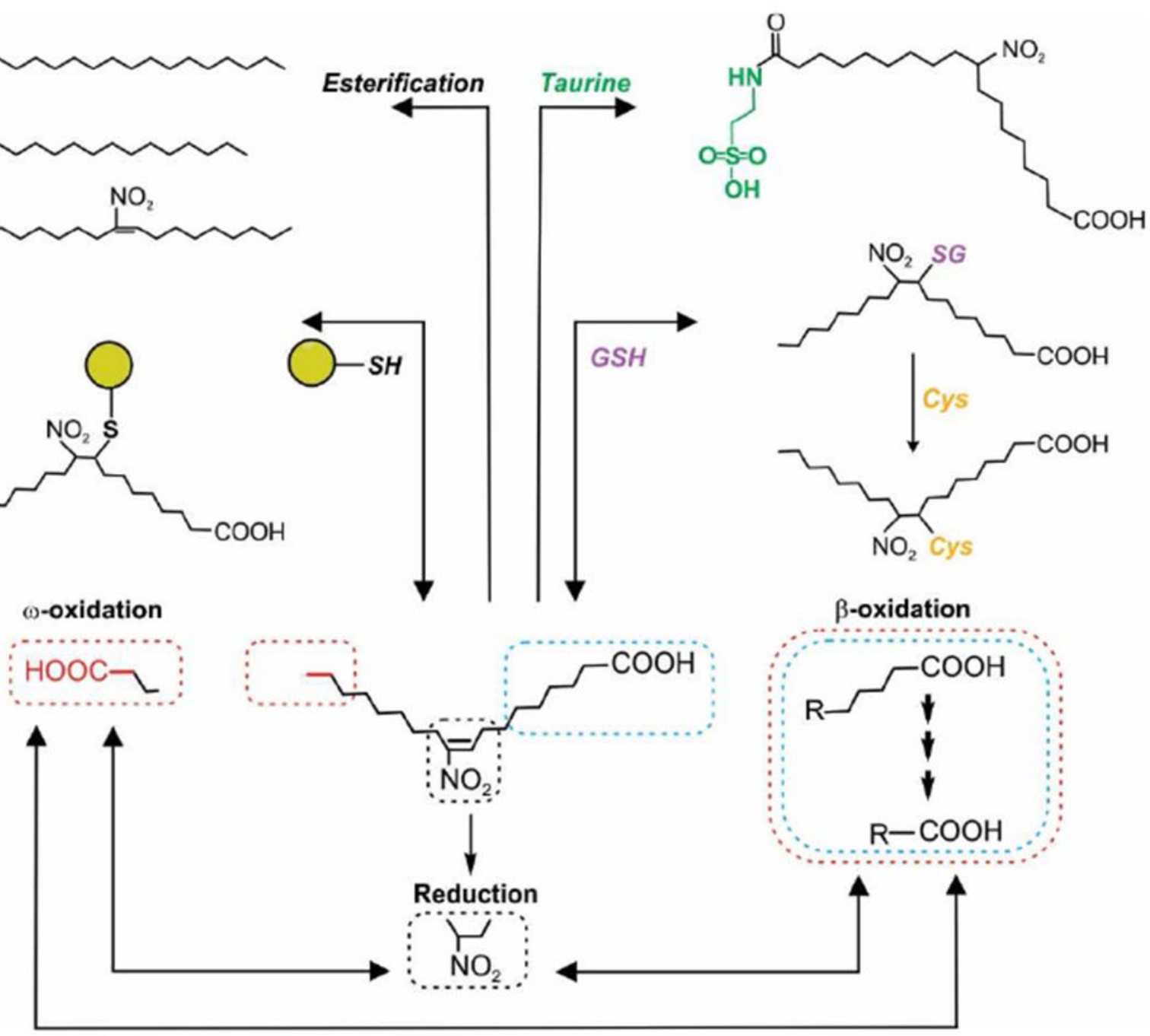

Figure 4: Routes of $\mathrm{NO}_{2}$-FA metabolism.

$\mathrm{NO}_{2}$-FA form reversible covalent adducts with reactive thiols and can also be incorporated into complex lipids. Free species of $\mathrm{NO}_{2}$-FA and metabolites are detected in plasma, tissue and urine. $\mathrm{NO}_{2}$-FA are reduced to non-electrophilic nitroalkanes by prostaglandin reductase and both nitroalkanes and alkenes undergo $\beta$-oxidation. In urine dicarboxylic acids resulting from $\omega$ oxidation were found as well as taurine and GSH derived conjugates. 